OPEN ACCESS

Edited by:

Umakanta Jena,

Desert Research Institute, USA

Reviewed by:

Sandeep Kumar,

Old Dominion University, USA Kaushlendra Singh,

West Virginia University, USA

${ }^{*}$ Correspondence:

Fernanda Vargas e Silva, Instituto de Pesquisas Hidráulicas, Bento Gonçalves 9500, Porto Alegre,

Rio Grande do Sul, Brazil fervs@globo.com

Specialty section:

This article was submitted to Bioenergy and Biofuels, a section of the journal Frontiers in Energy

Research

Received: 16 July 2014 Accepted: 10 June 2015

Published: 30 June 2015

Citation:

Vargas e Silva F and Monteggia LO (2015) Pyrolysis of algal biomass obtained from high-rate algae ponds applied to wastewater treatment.

Front. Energy Res. 3:31. doi: 10.3389/fenrg.2015.00031

\section{Pyrolysis of algal biomass obtained from high-rate algae ponds applied to wastewater treatment}

\author{
Fernanda Vargas e Silva* and Luiz Olinto Monteggia \\ Institute of Hydraulic Research, Federal University of Rio Grande do Sul, Porto Alegre, Brazil
}

This work presents the results of the pyrolysis of algal biomass obtained from high-rate algae ponds treating sewage. The two high-rate algae ponds (HRAP) were built and operated at the São João Navegantes Wastewater Treatment Plant. The HRAP A was fed with raw sewage while the HRAP B was fed with effluent from an upflow anaerobic sludge blanket (UASB) reactor. The HRAP B provided higher productivity, presenting total solids concentration of $487.3 \mathrm{mg} / \mathrm{l}$ and chlorophyll a of $7735 \mathrm{mg} / \mathrm{l}$. The algal productivity in the average depth was measured at $41.8 \mathrm{~g} \cdot \mathrm{m}^{-2}$ day $^{-1}$ in pond $A$ and at $47.1 \mathrm{~g} \cdot \mathrm{m}^{-2}$ day $^{-1}$ in pond B. Algae obtained from the HRAP B were separated by the process of coagulation/flocculation and sedimentation. In the presence of alum, a separation efficiency in the range of $97 \%$ solid removal was obtained. After centrifugation the biomass was dried and comminuted. The biofuel production experiments were conducted via pyrolysis in a tubular quartz glass reactor which was inserted in a furnace for external heating. The tests were carried out in an inert nitrogen atmosphere at a flow rate of $60 \mathrm{ml} / \mathrm{min}$. The system was operated at 400,500 , and $600^{\circ} \mathrm{C}$ in order to determine the influence of temperature on the obtained fractional yields. The studies showed that the pyrolysis product yield was influenced by temperature, with a maximum liquid phase (bio-oil and water) production rate of $44 \%$ at $500^{\circ} \mathrm{C}, 45 \%$ for char and around $11 \%$ for gas.

Keywords: high-rate algae ponds, pyrolysis, biofuels, wastewater treatment, bioremediaiton

\section{Introduction}

Biomass is considered worldwide as an important source of renewable energy, including electricity, automobile fuel, and as a source of heat for industrial equipment.

Cultures commonly used for energy production are sugarcane, corn, beans, beets, and many others. There are two main factors that define when a culture is appropriate for this process: good dry matter yield per unit of land (dry ton/ha), low area requirement for cultivation, and low costs of energy production from biomass (Dermibas et al., 2009).

However, some research has condemned the use of biofuels, associating its production with possible high food prices. Algae, among the aquatic biomass feedstocks, are considered one of the most promising sources of biofuels due to their unique characteristics. They can accumulate lipids that can be converted into biofuels, present fast proliferation, have the ability to sequester $\mathrm{CO}_{2}$ from the atmosphere for growth and do not require agricultural land or freshwater for growth or higher water consumption, and also the whole plant matter can be used in converting biofuels processes 
(Dismukes et al., 2008; Brennan and Owende, 2010; Jena and Das, 2011; Pate et al., 2011; Yanik et al., 2013; Zhou et al., 2014; Hognon et al., 2015).

Wastewater treatment associated with algae cultivation can offer an alternative way for sustainable renewable biofuels, since the large amount of freshwater needed for algae cultivation can be saved, becoming an environmentally friendly process (Zhou et al., 2014).

In a sewage treatment system, high-rate ponds are characterized by having high algal biomass generation which is an undesirable byproduct for the environment. Its presence in water bodies decreases water quality.

High-rate algae ponds are raceway-type ponds, in which water, algae, and nutrients are continually mixed. A paddle wheel generates a mean horizontal water velocity of approximately $0.15-0.3 \mathrm{~m} / \mathrm{s}$. This movement is necessary to avoid sedimentation and stratification. The maximum biomass production (mostly algae) is achieved through better use of lighting per volume. This is ensured by the low depth of the ponds and the constant movement of biomass through mechanical mixing (Nascimento, 2001; Chisti, 2007).

Usually the algal biomass productivity is determined by the measurement of solids found in the ponds.

The algal biomass production costs are mainly covered by the costs of treatment when using wastewater high-rate ponds resulting in lower environmental impacts in terms of water, energy, and fertilizer needs.

The biomass in high-rate algae ponds assimilates the nutrients needed for its growth and becomes responsible for the removal of nutrients from wastewater. This has the advantage of controlling pollution of water resources which contributes to the sustainable use of this technology on an industrial scale (Park et al., 2011; Passos et al., 2013).

The biomass separation process requires an increase in algal suspension concentration typically from 0.02 to $0.06 \%$ total suspended solids (TSS) to approximately 2 to $7 \%$ solids, which may be higher depending on the target process objective (Uduman et al., 2010).

The algal cells have reduced size, sometimes $<30 \mu \mathrm{m}$ and their density is similar to water with a low sedimentation rate, so to be successful in separation, it is necessary to aggregate the cells. Generally, the process comprises of two steps: the first involving destabilization of algal cells using coagulation followed by sedimentation or flotation. In the second step of the process, it is necessary to increase the biomass content, which is often done by filtration, centrifugation, or thermal processes (Molina Grima et al., 2003; Granados et al., 2012; Cai et al., 2013; Udom et al., 2013).

The algae cell has a negative surface charge, which prevents aggregation. This charge may be reduced or neutralized by the addition of flocculants or multivalent cations, such as cationic polymers that change the zeta potential, which is a measure of particle stability, reducing the repulsive forces. So the action of the attractive Van der Waals forces allows algae agglutination (Wessler et al., 2003; Granados et al., 2012). Salts used for this purpose should be non-toxic, low cost, and have high effectiveness at low concentrations (Molina Grima et al., 2003).

Another advantage of using coagulation/flocculation process is nutrient removal. The presence of nutrients in wastewater, particularly nitrogen and phosphorus, is a serious environmental problem and is receiving increasing attention. Nitrogen in the form of ammonia can be volatilized and cause air pollution. Phosphorus can permeate into the soil and cause damage to the underground water (Chen et al., 2012). When there are excessive levels of nutrients in the wastewater, they cause eutrophication of water sources, possibly damaging the ecosystem (Cai et al., 2013).

The algal biomass, after thickening, may reach $5-15 \%$ solid content, and, being perishable, it must be processed as soon as possible. Essential processes such as thickening and drying usually involve high operational costs. Thus, these steps are considered determining factors regarding the economical feasibility analysis of the overall process (Brennan and Owende, 2010; Uduman et al., 2010). The methods commonly used for thickening biomass are centrifugation and filtration followed by different drying techniques, such as natural, oven, spray, and fluidized bed drying.

There are three basic components in algae biomass: proteins, carbohydrates, and lipids. These oils can then be extracted and converted in to biofuels (Um and Kim, 2009).

The pyrolysis process appears to be an excellent alternative for energy conversion, it presents the advantage of using different sources of organic matter, not being limited by the lipid content, as with biodiesel production processes. The pyrolysis process is based on decomposition of organic compounds present in the total biomass under a controlled environment in the absence of oxygen and atmospheric pressure, resulting in different phases: liquid (biooil), gas, and solid (char). It is an endothermic reaction that occurs at a temperature of $300-700^{\circ} \mathrm{C}$ depending on the characteristics of the material to be pyrolyzed (Martini, 2009; Hognon et al., 2015).

Biomass pyrolysis is considered a renewable process, because biomass is turned in several gases when pyrolyzed. Carbon dioxide, one of the gases formed, is absorbed by the algae for its growth, making the process self-sustainable with no serious contribution to greenhouse effect. The relative yield of each phase generated in the process depends on operating parameters (temperature, heating rate, residence time, and flow rate of inert gas), properties of the biomass (the particle size as well as its moisture), and type of pyrolysis used (slow, fast, or flash pyrolysis) (Balat et al., 2009; Martini, 2009; Akhtar and Amin, 2012; Yanik et al., 2013; Hognon et al., 2015).

In order to obtain high yields of aqueous products, fast pyrolysis is normally used, which is characterized by higher heating rates $\left(1000^{\circ} \mathrm{C} / \mathrm{min}\right)$ and lower residence times of volatiles $(10-20 \mathrm{~s})$. In order to favor solid char formation, slow pyrolysis process with lower heating rates $\left(5-80^{\circ} \mathrm{C} / \mathrm{min}\right)$ and longer residence times (5-30 min) must be used (Van de Velden et al., 2010; Jena and Das, 2011; Yanik et al., 2013).

The bio-oil generated by biomass pyrolysis is generally cleaner than that from fossil fuels, due to its lower nitrogen and sulfur content. The biomass vaporizes, passes through a process of cracking and condensation, producing a dark brown liquid, consisting of a complex mixture of many different hydrocarbons. This process is most successful in fluidized bed reactors due to high heating rates, rapid devolatilization and easy control (Doshi et al., 2005; Martini, 2009). 


\section{Materials and Methods}

\section{Biomass Production}

Two high-rate algae ponds were constructed in the IPH/UFRGS experimental wastewater treatment unit, at São João Navegantes Wastewater Treatment Plant, This plant is responsible for handling the sewage of the north area of Porto Alegre/RS.

The ponds were operated in closed circuit with the following dimensions: overall height: $0.9 \mathrm{~m}$, length of the straight sections: $30 \mathrm{~m}$, width: $5 \mathrm{~m}$ (at the upper edge of the slope) and surface area $320 \mathrm{~m}^{2}$, as can be seen in Figure 1 .

The high-rate algae ponds were operated under two feeding conditions: pond A was fed with raw sewage after pretreatment (screening and grit removal) and pond B was fed with effluent from an upflow anaerobic sludge blanket (UASB) reactor. In order to maximize the process of biomass production, the operating parameters of the ponds were useful depth $(\mathrm{Hu}): 0.3 \mathrm{~m}$, longitudinal flow speed: $0.3 \mathrm{~m} / \mathrm{s}$, and hydraulic detention time (HDT): 3 days.

The pond samples were collected in $20 \mathrm{l}$ plastic containers, directly from the body of the ponds, to provide enough biomass for the pyrolysis experiments.

In order to determine algae biomass productivity, total solids, turbidity, and chlorophyll a were measured weekly.

All experiments to determine these parameters were carried out according to Standard Methods for the Examination of Water and Wastewater [American Public Health Association (APHA) and Awwa (2005)].

\section{Algae Separation and Thickening}

Experiments of coagulation/flocculation were performed using the effluent from pond $\mathrm{B}$, which showed better performance in terms of algal biomass production.

The equipment used was VELP Jar Test model F.6/S, composed of 6 jars of $2000 \mathrm{ml}$ each, with agitation and controlled independently.

To evaluate the separation process and the removal of nutrients two coagulants were used, Aluminum Sulfate and Ferric Chloride and two flocculants, Sulfloc 1001 and Tanfloc SL. Their concentration ranges are shown in Table 1.

After the separation and removal of all the supernatant from the jars, the algae sludge was submitted to centrifugation for $20 \mathrm{~min}$ at $2500 \mathrm{rpm}$ to obtain a sample of about $15-20 \%$ of dried solids. After centrifugation, the biomass was dried at $105^{\circ} \mathrm{C}$. Finally, the dried algae were ground in a mortar and stored separately according to the reagent used in the separation process.

\section{Nutrient Removal}

Experiments were performed to determine the concentration of nitrogen and phosphorus in effluent ponds before and after coagulation/flocculation. Thus, it was possible to determine the effect of algae upon the separation in the removal of nutrients.

\section{Biomass Pyrolysis}

The experiments obtaining biofuel via biomass pyrolysis were performed in a tubular quartz reactor, with the dimensions described in Figure 2.

The experiments were run in batches, to allow solid char removal. The process flow used in this work, presented in Figure 3, was based on Zhang et al. (2011).

In the process, the inert atmosphere was generated by nitrogen gas (1) and the heating process was provided by an external furnace (2). The condensation was performed in (3), where two condensers in series were immersed in an ice bath. The exit of non-condensable gases was in (4).

The pyrolysis reactor was fed manually with $7 \mathrm{~g}$ of dried and ground biomass obtained from the previous step of the process. The biomass was inserted in the reactor using an aluminum foil capsule. After it has been charged, the reactor was closed and the inert atmosphere was provided by a $0.06 \mathrm{l} / \mathrm{min}$ nitrogen gas flow.

The pyrolysis runs were started by placing the reactor in a programable tubular furnace, with a heating rate of $20^{\circ} \mathrm{C} / \mathrm{min}$. All the runs were made in two steps: heating the sample and an isothermal reaction step, maintaining the desired temperature $\left(400,500\right.$, and $\left.600^{\circ} \mathrm{C}\right)$ for $60 \mathrm{~min}$.

The vapors generated passed through two condensers in series, immersed in ice baths maintained at a temperature of about $0^{\circ} \mathrm{C}$. At the end of each experiment, the aqueous phase generated by condensation was collected, combined, weighed, and stored. The non-condensable gases were measured by difference. Following the $60 \mathrm{~min}$ reaction time, the system was turned off and cooled to room temperature.

After reaching room temperature, the reactor was opened and the solid fraction (char) was collected, weighed, and stored. The

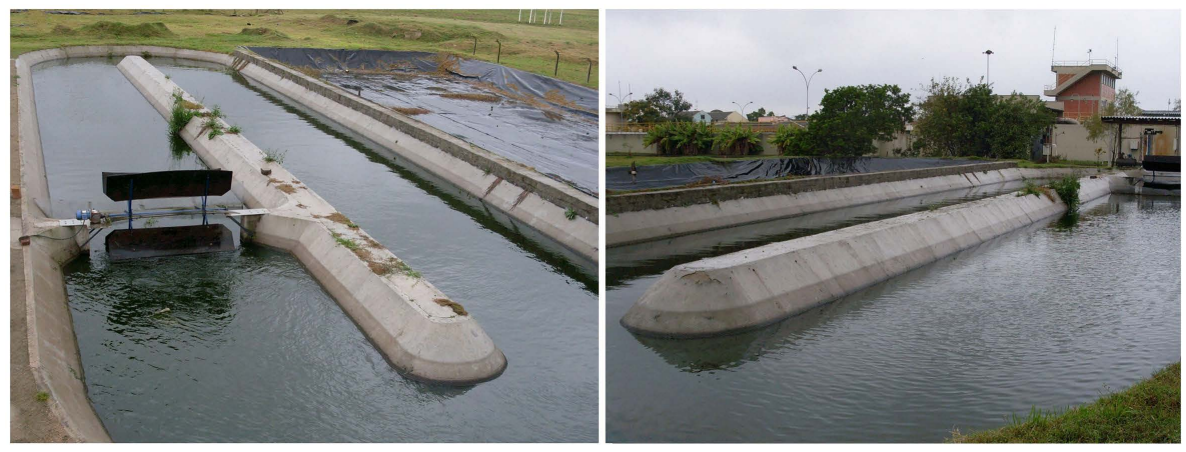

FIGURE 1 | High-rate algae ponds. 
TABLE 1 | Concentration range used.

\begin{tabular}{lcccc}
\hline Product & $\mathbf{F e C l}_{\mathbf{3}} \mathbf{1 0} \%$ & $\mathbf{A l}_{\mathbf{2}}\left(\mathbf{S O}_{\mathbf{4}}\right)_{\mathbf{3}} \mathbf{1 0} \%$ & Sulfloc 20\% & Tanfloc 10\% \\
\hline $\begin{array}{l}\text { Concentration } \\
\text { range }(\mathrm{mg} / \mathrm{l})\end{array}$ & $200-300$ & $100-150$ & $250-300$ & $50-100$ \\
& & & &
\end{tabular}

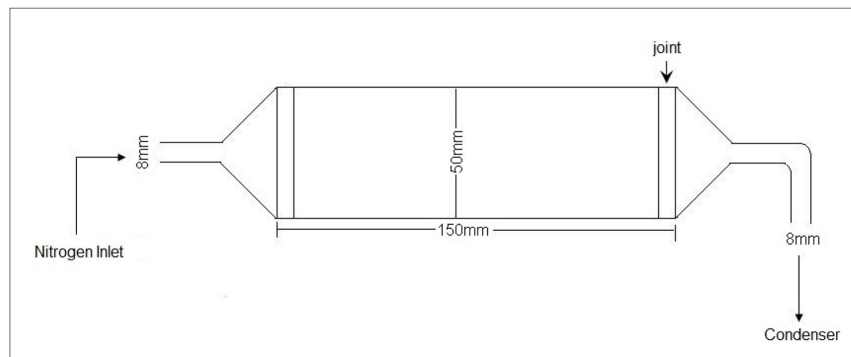

FIGURE 2 | Pyrolysis reactor

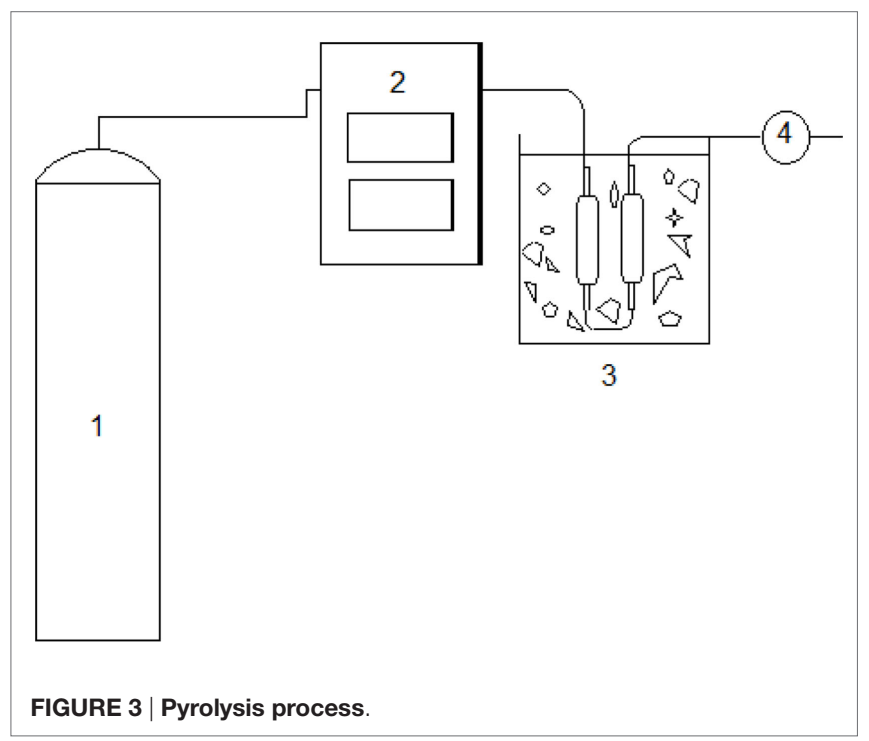

reactor final mass was also determined, in order to measure the losses by wall adhesion.

The pyrolysis evaluation was performed through yields measurement. Each fraction was determined from the ratio of the weight of respective fraction to initial weight of biomass, expressed as percentage yield, according to Eq. (1).

Yield $(\%)=\frac{\text { Fraction mass obtained after pyrolysis }}{\text { Initial algae biomass }} \times 100 \%$

\section{Results and Discussions}

\section{Biomass Production}

The results of solids, turbidity, chlorophyll a and productivity are shown in Table 2, comparing the performance of both biomass production ponds.

In the experiments, we considered the concentration of solids present in effluents and turbidity caused only by the presence of algae. From Table 2, it can be noted that pond B in all evaluation parameters showed higher values than those obtained from pond A. Such behavior is explained by the fact that effluent from UASB
TABLE 2 | High-rate ponds performance.

\begin{tabular}{|c|c|c|c|c|}
\hline Analysis & Pond A & SD & Pond B & SD \\
\hline Total solids (mg/l) & 433.2 & 59.2 & 487.3 & 56.1 \\
\hline Turbidity (NTU) & 41.9 & 8.9 & 63.3 & 13.4 \\
\hline Chlorophyll a (mg/l) & 2338 & NA & 7735 & NA \\
\hline Productivity $\left(\mathrm{g} \cdot \mathrm{m}^{-2}\right.$ day $\left.^{-1}\right)$ & 41.8 & NA & 47.1 & NA \\
\hline
\end{tabular}

NA, not applicable.

TABLE 3 | Algae biomass productivity.

\begin{tabular}{llc}
\hline Authors & System & $\begin{array}{c}\text { Biomass productivity } \\
\left(\mathbf{g} \cdot \mathbf{m}^{-\mathbf{2}} \mathbf{~ d a y ~}^{\mathbf{- 1}} \mathbf{)}\right.\end{array}$ \\
\hline Nascimento (2001) & HRAP & 21.8 \\
Riaño et al. (2012) & Photobioreactor & 1.54 \\
Sturm and Lamer (2011) & Open ponds & 12 \\
Terigar and Theegala (2014) & Open tanks & 43.4
\end{tabular}

TABLE 4 | Crops productivity [adapted from Trzeciak et al. (2008)].

\begin{tabular}{lcc}
\hline Crops & $\begin{array}{c}\text { Harvest (month/ } \\
\text { year) }\end{array}$ & $\begin{array}{c}\text { Biomass productivity } \\
\left(\mathbf{g} \cdot \mathbf{m}^{-\mathbf{2}} \mathbf{~ d a y ~}^{-\mathbf{1}} \mathbf{)}\right.\end{array}$ \\
\hline Cotton & 3 & 0.38 \\
Peanut & 3 & 0.55 \\
Canola & 3 & 0.60 \\
Sunflowers & 3 & 0.55 \\
Dendê (Elaeis guineensis) & 12 & 6.84 \\
Mamona (Ricinus communis L.) & 3 & 0.41
\end{tabular}

reactor provided low solid concentration, which facilitated higher solar irradiation in the body of the pond, an essential factor for biomass growth. Thus, the effluent selected for tests of separation, thickening, and the tests for obtaining biofuels was collected from the pond B. Table 3 shows a comparison among biomass productivity obtained in this work and others presented in the literature.

Table 4 shows the comparison between the productivity of crops commonly used in the biofuels production.

As we can see from both tables, high-rate algae ponds can be a competitive source of biomass, with higher productivities and without need of arable land and fresh water. This system high-rate algae pond (HRAP) presents no seasonality and the biomass can be harvested all year, without competition with food crops.

\section{Algae Separation, Thickening, and Nutrient Removal}

The results of algae separation are shown in Table 5, based on separation efficiency related to the chemical dosage used. This table also shows the evaluation of nutrient removal for each product.

Thus, according to the results shown in Table 5, the biomass separated with aluminum sulfate, which was selected as the most convenient chemical due to lower dosage requirement, showed better separation and nutrient removal. The biomass was dried and crushed to be used in the pyrolysis experiments. The efficiency of $\mathrm{N}$ and P removal were similar when using Sulfloc $20 \%$, but the dosage required was higher than with sulfate.

\section{Biomass Pyrolysis}

The influence of temperature $\left(400,500\right.$, and $\left.600^{\circ} \mathrm{C}\right)$ on pyrolysis results are shown in Figure 4. According to the results, the 
TABLE 5 | Removal obtained and dosage used.

\begin{tabular}{lcccc}
\hline Product & $\begin{array}{c}\text { Ferric chloride } \\
\mathbf{1 0 \%}\end{array}$ & $\begin{array}{c}\text { Al sulfate } \\
\mathbf{1 0 \%}\end{array}$ & $\begin{array}{c}\text { Sulfloc } \\
\mathbf{2 0 \%}\end{array}$ & $\begin{array}{c}\text { Tanfloc } \\
\mathbf{1 0 \%}\end{array}$ \\
\hline Maximum separation (\%) & 88.4 & 97.9 & 94.5 & 97.5 \\
Concentration (mg/l) & 300 & 150 & 290 & 100 \\
P Removal (\%) & 100 & 100 & 100 & 37.9 \\
N Removal (\%) & - & 5.5 & 5.5 & -
\end{tabular}

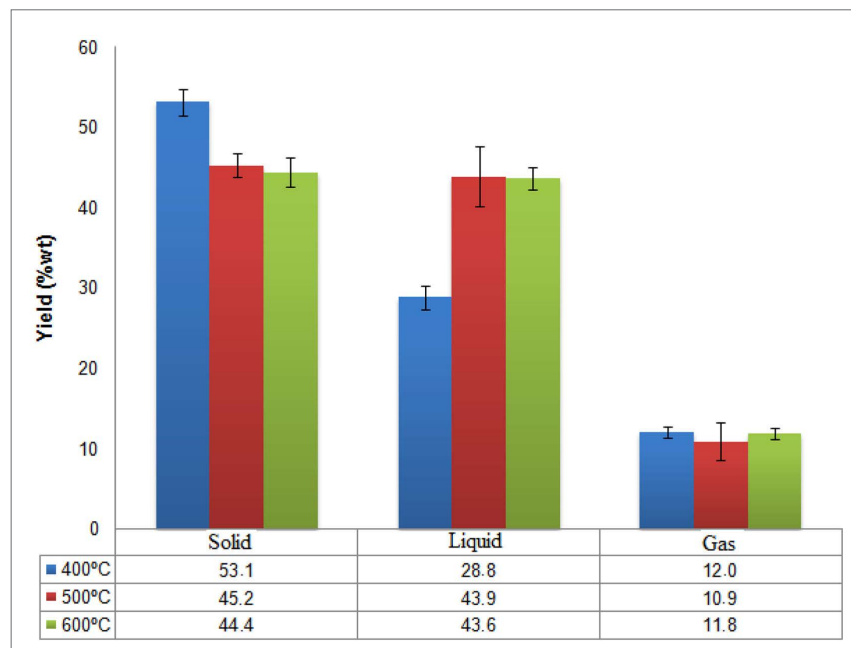

FIGURE 4 | Influence of temperature on pyrolysis products

temperature of $400^{\circ} \mathrm{C}$ favors solid phase formation, with an average yield of $53.1 \%$. The aqueous and gaseous phases obtained average yields of 28.8 and $12 \%$, respectively. At $500^{\circ} \mathrm{C}$, the yields for solid and aqueous phases were similar, however aqueous phase formation was slightly higher, composed of bio-oil and water. The average yield was 43.9 for solid phase 45.2 for the aqueous phase and $10.9 \%$ in the gas phase. At $600^{\circ} \mathrm{C}$ we can see similar yields between solid and liquid formation, 44.4 and $43.6 \%$, respectively. The average for gas formation at this temperature was $11.8 \%$.

The liquid phase, comprising of bio-oil and water, has a reddish brown color, with a strong and distinctive smoky smell, which

\section{References}

Akhtar, J., and Amin, N. S. (2012). A review on operating parameters for optimum liquid oil yield in biomass pyrolysis. Renew. Sustain. Energ. Rev. 16, 5101-5109. doi:10.1016/j.rser.2012.05.033

American Public Health Association (APHA) and Awwa, W. E. F. (2005). Standard Methods for the Examination of Water and Waste Water, 21st Edn. American Public Health Association, 4-108; 4-147.

Balat, M., Balat, M., Kirtay, E., and Balat, H. (2009). Main routes for thermo-conversion of biomass into fuels and chemicals. Part1: pyrolysis systems. Energy Convers. Manag. 50, 3147-3157. doi:10.1016/j.enconman.2009.08.014

Brennan, L., and Owende, P. (2010). Biofuels from microalgae - a review of technologies for production, processing and extractions of biofuels and co-products. Renew. Sustain. Energ. Rev. 14, 557-577. doi:10.1016/j.rser.2009.10.009

Cai, T., Park, S. Y., and Li, Y. (2013). Nutrient recovery from wastewater streams by microalgae: status and prospects. Renew. Sustain. Energ. Rev. 19, 360-369. doi:10.1016/j.rser.2012.11.030

Chen, R., Li, R., Deitz, L., Liu, Y., Stevenson, R. J., and Liao, W. (2012). Freshwater cultivation with animal waste for nutrient removal and biomass production. Biomass Bioenergy 39, 128-138. doi:10.1016/j.biombioe.2011.12.045 confirms the information in the literature about products obtained in the pyrolysis (Jena and Das, 2011; Yanik et al., 2013).

As described in the literature, temperature plays an important role on the yield of the fractions obtained in the pyrolysis process. Studies show that temperatures between 450 and $550^{\circ} \mathrm{C}$ maximize the yield of bio-oil and, and at very high temperatures, secondary reactions of the volatiles may occur, thus decreasing the yield of the liquid phase, which can be seen in Figure 4; at $600^{\circ} \mathrm{C}$, a small decrease in the aqueous phase yield was observed (Yanik et al., 2013).

For related data, we use an ANCOVA analysis (Analysis of Covariance) with a fixed factor (oven temperature) and a covariate (initial mass of algae) to identify differences in the char mass production. Five replicates were performed for each factor and the software used was SPSS version 18 .

The data do not present heteroscedasticity, using the Levene test ( $p$-value of 0.235 ), the tested factor was significant at a $p$-value of 0.01 . So we went to the post hoc analysis, which showed a significant difference between the means of groups, the $400^{\circ} \mathrm{C}$ group is different from other groups and the $500^{\circ} \mathrm{C}$ and $600^{\circ} \mathrm{C}$ are not statistically different from each other.

\section{Conclusion}

In this work, the association of wastewater treatment and biofuel production through pyrolysis of algal biomass obtained in high-rate algae ponds was studied. The algal productivity, at the average depth was measured as $41.8 \mathrm{~g} \cdot \mathrm{m}^{-2}$ day $^{-1}$ for pond $A$ and as $47.1 \mathrm{~g} \cdot \mathrm{m}^{-2}$ day $^{-1}$ for pond $\mathrm{B}$. The algae were pyrolyzed in a tubular furnace system with external heating at different temperatures. Studies have shown that the pyrolysis process is efficient and the fractions yields are greatly influenced by temperature. Operating under mild conditions, it was possible to obtain maximum yields of $45 \%$ at $500^{\circ} \mathrm{C}$ for aqueous phase (bio-oil and water), $44 \%$ for char, and about $11 \%$ for gas. As we can see, through this process, it is possible to offer a promising alternative for environmental pollution control with potential economic return.

\section{Acknowledgments}

The authors acknowledge $\mathrm{CNPq}$ and CAPES for the financial support to this project.

Dermibas, M. F., Balat, M., and Balat, H. (2009). Potential contribution of biomass to the sustainable energy development. Energy Convers. Manag. 50, 1746-1760. doi:10.1016/j.enconman.2009.03.013

Dismukes, G. C., Carrieri, D., Bennette, N., Ananyev, G. M., and Posewitz, M. C. (2008). Aquatic phototrophs: efficient alternatives to land-based crops for biofuels. Curr. Opin. Biotechnol. 19, 235-240. doi:10.1016/j. copbio.2008.05.007

Doshi, V. A., Vuthaluru, H. B., and Bastow, T. (2005). Investigations into the control of odor and viscosity of biomass oil derived from pyrolysis of sewage sludge. Fuel Process. Technol. 86, 885-897. doi:10.1016/j.fuproc.2004.10.001

Granados, M. R., Acién, F. G., Gómez, C., Fernandez-Sevilla, J. M., and Molina Grima, E. (2012). Evaluation of flocculants for the recovery of freshwater microalgae. Bioresour. Technol. 118, 102-110. doi:10.1016/j.biortech.2012.05.018

Hognon, C., Delrue, F., Texier, J., Gateau, M., Thiery, S., Miller, S., et al. (2015). Comparison of pyrolysis and hydrothermal liquefaction of Chlamydomonas reinhardti. Growth studies on the recovered hydrothermal aqueous phase. Biomass Bioenergy 73, 23-31. doi:10.1016/j.biombioe.2014.11.025

Jena, U., and Das, K. C. (2011). Comparative evaluation of thermochemical liquefaction and pyrolysis for bio-oil production from microalgae. Energy Fuels 25, 5472-5482. doi:10.1021/ef201373m 
Martini, P. R. R. (2009). Conversão Pirolítica de Bagaço Residual da Indústria de Suco de Laranja e Caracterização Química dos Produtos. Dissertação de Mestrado, PPGQ; Universidade Federal de Santa Maria, Santa Maria.

Molina Grima, E., Belarbi, E. H., Acién Fernández, F. G., Robles Medina, A., and Chisti, Y. (2003). Recovery of microalgal biomass and metabolites: process options and economics. Biotechnol. Adv. 20, 491-515. doi:10.1016/S0734-9750(02)00050-2

Nascimento, J. R. S. (2001). Lagoas de Alta Taxa de Produção de Algas Para PósTratamento de Efluentes de Reatores Anaeróbios. Dissertação de Mestrado, Instituto de Pesquisas Hidráulicas, UFRGS, Porto Alegre.

Park, J. B. K., Craggs, R. J., and Shilton, A. N. (2011). Wastewater treatment high rate algal ponds for biofuel production. Bioresour. Technol., 102, p. 35-42. doi:10.1016/j. biortech.2010.06.158

Passos, F., Solé, M., García, J., and Ferrer, I. (2013). Biogas production from microalgae grown in wastewater: effect on microwave pretreatment. Appl. Energy 108, 168-175. doi:10.1016/j.watres.2013.10.013

Pate, R., Klise, G., and Wu, B. (2011). Resource demand implications for US algae biofuels production scale-up. Appl. Energy 88, 3377-3388. doi:10.1016/j. apenergy.2011.04.023

Riaño, B., Hérnandez, D., and Garcia-González, M. C. (2012). Microalgal-based systems for wastewater treatment: effect of applied organic and nutrient loading rate on biomass composition. Ecol. Eng. 49, 112-117. doi:10.1016/j.ecoleng.2012. 08.021

Sturm, B. S. M., and Lamer, S. L. (2011). An energy evaluation of coupling nutrient removal from wastewater with algal biomass production. Appl. Energy 88, 3499-3506. doi:10.1016/j.apenergy.2010.12.056

Terigar, B. C., and Theegala, C. S. (2014). Investigating the interdependence between cell density, biomass productivity, and lipid productivity to maximize biofuel feedstock production from outdoor microalgal cultures. Renew. Energy 64, 238-243. doi:10.1016/j.renene.2013.11.010

Trzeciak, M. B., das Neves, M. B., da Silva Vinholes, P., and Amaral Villela, F. (2008). Utilização de sementes de species oleaginosas para produção de biodiesel. Inf. Abrates 18, 30-38.

Udom, I., Zaribaf, B. H., Halfhide, T., Gillie, B., Dalrymple, O., Zhang, Q., et al. (2013). Harvesting microalgae grown on wastewater. Bioresour. Technol. 139, 101-106. doi:10.1016/j.biortech.2013.04.002
Uduman, N., Ying, Q., Danquah, M. K., Forde, G. M., and Hoadley, A. (2010) Dewatering of microalgal cultures: a major bottleneck to algae-based fuels. J. Renew. Sustain. Energy 2. doi:10.1063/1.3294480

Um, B. H., and Kim, Y. S. (2009). Review: a chance for Korea to advance algal-biodiesel technology. J. Ind. Eng. Chem. 15, 1-7. doi:10.1016/j.jiec.2008.08.002

Van de Velden, M., Baeyens, J., Brems, A., Janssens, B., and Dewil, R. (2010) Fundamentals, kinetics and endothermicity of the biomass pyrolysis reaction. Renew. Energy 35, 232-242. doi:10.1016/j.renene.2009.04.019

Wessler, R. A., Amorim, S., and Cavalli, V. (2003). Estudo da Viabilidade Técnica e Econômica da Utilização de um Polímero Orgânico Natural Catiônico em Substituição ao Sulfato de Alumínio Convencionalmente Utilizado em Estações de Tratamento de Água (ETA'S). Artigo Técnico. Santo André: 33 Assembleia Nacional dos Serviços Municipais de Saneamento; ASSEMAE. Available at: http://www.semasa.sp.gov. br/Documentos/ASSEMAE/Trab_29.pdf

Yanik, J., Stahl, R., Troeger, N., and Sinag, A. (2013). Pyrolysis of algal biomass. J. Anal. Appl. Pyrolysis 103, 134-141. doi:10.1016/j.jaap.2012.08.016

Chisti, Y. (2007). Biodiesel from microalgae. Research review paper. Biotechnol. Adv. 25, 294-306. doi:10.1016/j.biotechadv.2007.02.001

Zhang, B., Xiong, S., Xiao, B., Yu, D., and Jia, X. (2011). Mechanism of wet sludge pyrolysis in a tubular furnace. Int. J. Hydrogen Energy 36, 355-363. doi:10.1016/j. ijhydene.2010.05.100

Zhou, W., Chen, P., Min, M., Ma, X., Wang, J., Griffith, R., et al. (2014). Environmentenhancing algal biofuel production using wastewaters. Renew. Sustain. Energ. Rev. 36, 256-269. doi:10.1016/j.rser.2014.04.073

Conflict of Interest Statement: The authors declare that the research was conducted in the absence of any commercial or financial relationships that could be construed as a potential conflict of interest.

Copyright (C) 2015 Vargas e Silva and Monteggia. This is an open-access article distributed under the terms of the Creative Commons Attribution License (CC BY). The use, distribution or reproduction in other forums is permitted, provided the original author(s) or licensor are credited and that the original publication in this journal is cited, in accordance with accepted academic practice. No use, distribution or reproduction is permitted which does not comply with these terms. 